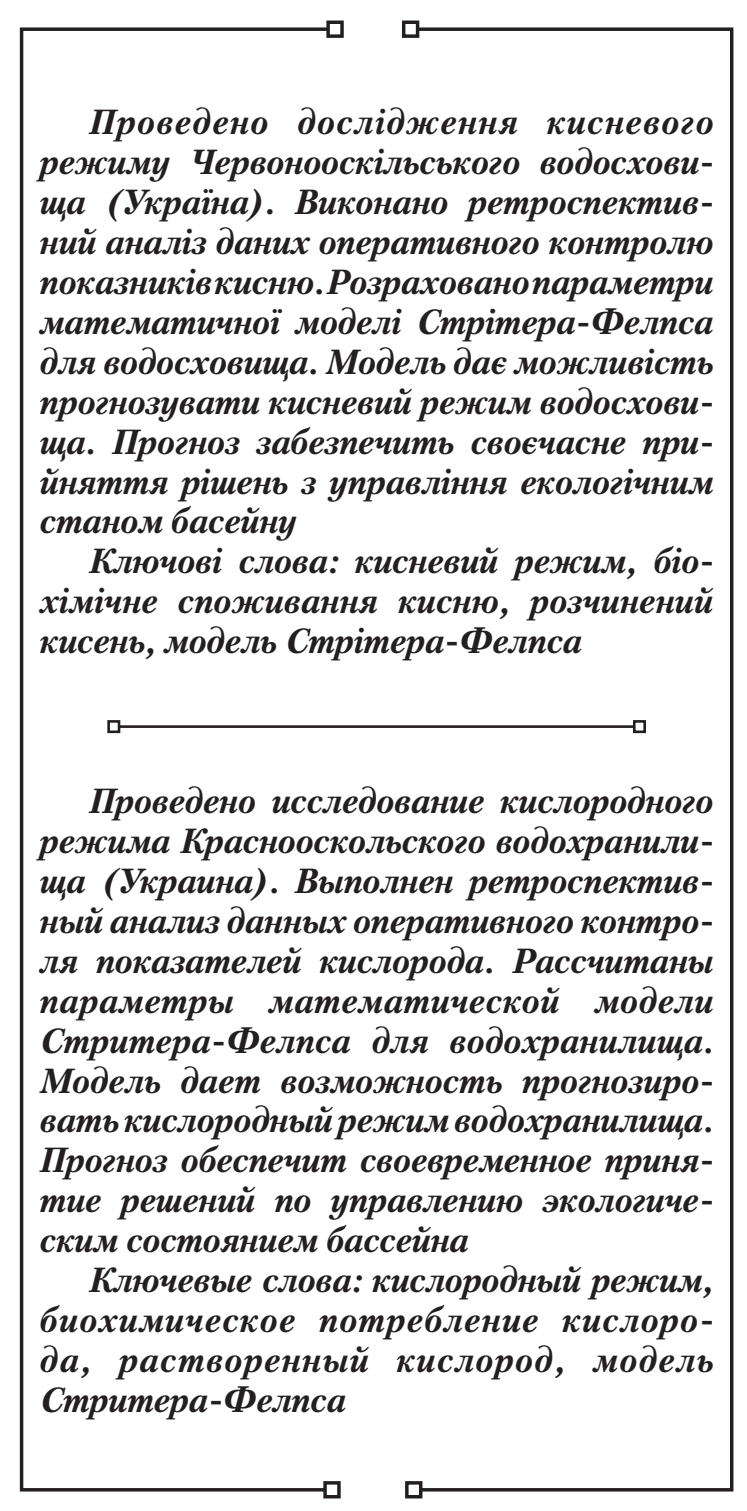

UDC 504.45

DOI: $10.15587 / 1729-4061.2017 .109477$

\section{EXAMINING THE DYNAMICS AND MODELING OF OXYGEN REGIME OF CHERVONOOSKIL WATER RESERVOIR}

\author{
V. Bezsonny i \\ Lead Engineer \\ Educational center "Megapolis"* \\ E-mail: bezsonny@gmail.com \\ O. Tret y a kov \\ Doctor of Technical Sciences, Associate Professor \\ Department of Safety of Vital Activity* \\ E-mail: mega_ovtr@ukr.net \\ B. Khalmuradov \\ $\mathrm{PhD}$, Associate Professor \\ Department of Safety of life \\ National Aviation University \\ Kosmonavta Komarova ave., 1, Kyiv, Ukraine, 03058 \\ E-mail: batyrk@ukr.net \\ R. Pon om a re n ko \\ $\mathrm{PhD}$, Senior Researcher \\ Department of fire and rescue training \\ National University Civil Protection of Ukraine \\ Chernyshevska str., 94, Kharkiv, Ukraine, 61023 \\ E-mail:prv@nuczu.edu.ua \\ *O. M. Beketov National University of Urban Economy in Kharkiv \\ Marshala Bazhanova str., 17, Kharkiv, Ukraine, 61002
}

\section{Introduction}

The Chervonooskil water reservoir is located within Kharkiv and Donetsk oblasts (Ukraine) and was created by means of regulation of the flow of the Oskil river - the first-order tributary of the Siversky Donets river. By the project purpose, the reservoir is the main source of the centralized economic water supply of Donbas. The reservoir is supposed to be used for irrigation, needs of the fishing industry and rest of the population [1].

The country's drinking water supply is almost by $80 \%$ provided by surface sources. That is why the quality and the state of water in surface water bodies is a significant factor for sanitary and hygienic well-being of the population [2].

The problems in the field of environmental safety of surface waters have been becoming increasingly acute recently, which is caused by unsatisfactory condition of water resources. Among the reasons, it is necessary to mention the lack of efficient mechanisms in implementation of the basin principle of water management, control and responsibility. This situation is due to the historical development and location of industrial sites. The main pollutants of surface sources of drinking water supply are found in the same area (oblast) and preparation for production of drinking water and its consumption are carried out on other territory. This is especially true for water reservoirs, since they are created for accumulation of water reserves and complex economic use.

Oxygen is essential for existence of most aquatic organisms and one of the most powerful natural oxidants, performing the sanitary-hygienic role in a water body. Oxygen belongs to the most important dissolved gases; its content largely determines the quality of water. Due to its properties, oxygen intensifies its self-purification processes, physical-chemical transformations and hydrobiological circulation of substances.

Concentration of oxygen, dissolved in water, is an integral magnitude that is determined by the ratio of differently oriented physical-chemical, hydrodynamic and hydro-biological processes that occur in the aquatic environment and on the separation boundary "water - atmosphere" [1].

The main source of oxygen supply to surface waters is atmospheric air. In addition, much oxygen is released by plants in the process of photosynthesis [3]. Oxygen demand is related to chemical and biochemical processes of oxidation of organic and some inorganic substances, as well as to breathing of aquatic organisms [4]. Oxygen is consumed at 
different rate, depending on temperature, number of bacteria, and other water organisms and substances.

Oxygen concentration in surface waters varies considerably depending on the season and time of day, under normal conditions its content in surface waters can vary from 0 to $14 \mathrm{mg} / \mathrm{dm}^{3}$. The minimum content of dissolved oxygen for provision of the normal development of fish is $5 \mathrm{mg} / \mathrm{dm}^{3}$, and its decrease to $2 \mathrm{mg} / \mathrm{dm}^{3}$ causes mass death of aquatic animals. But oversaturation of water with oxygen can also negatively affect the development of hydrobionts.

In accordance with the requirements to the composition and quality of water of reservoirs at points of using drinking and sanitary water, content of dissolved oxygen in water must not be lower than $4 \mathrm{mg} / \mathrm{dm}^{3}$ in any season. According to fishing industry standards, oxygen concentration in water in winter must be higher than or equal to $4 \mathrm{mg} / \mathrm{dm}^{3}$, and in summer - not lower than $6 \mathrm{mg} / \mathrm{dm}^{3}$ [5].

Seversky Donets River basin, which includes the Chervonooskil reservoir, is one of the most complex among river basins of Ukraine. Formation of chemical composition and quality of water of the basin goes on under non-homogeneous natural conditions and under the influence of significant anthropogenic load. The studies, carried out earlier, indicate insufficient oxygen supply to the surface waters of the Seversky Donets basin [3, 4, 6-8].

That is why study and modeling of dynamics of oxygen regime of the Chervonooskil reservoir, particularly indicators of dissolved oxygen (DO) and biochemical oxygen demand (BOD) are relevant both at current water use and for the process of implementation of the integrated water resources management.

\section{Literature review and problem statement}

One of the main ways that help solve problems related to the quality of surface waters, is mathematical modeling. After constructing a mathematical model of the dynamics of water quality, it is possible to determine the degree and depth of treatment, compliance with the standards of drinking water and commercial use. It is also possible to determine water quality at any point of the reservoir at any time and to develop a set of measures, necessary to bring that quality to the conformity with recreational or fishing industrial requirements. Using the model, we can predict consequences of the influence of untreated or insufficiently treated wastewater, discharged to the water body, on water quality, etc.

The source information for problems of water quality modeling is results of observations. Modeling and observations are closely related. Water quality modeling is possible with availability of information about quality (direct link). Construction of a model involves knowing the patterns of changes of the water environment and the possibility of mathematical calculations (feedback).

To characterize the range of processes that really affect water quality, rather complicated equations are used because a change in the concentration of one component will automatically affect the others, which is caused by the law of conservation of matter. Using the Streeter-Phelps equations [1] enables us to evaluate the full range of pollutants, discharged to aquatic site, oxygen demand and compensating influence of atmospheric aeration.

In Ukraine and in the world, a lot of research is devoted to modeling and analysis of the content of dissolved oxygen in water and biochemical oxygen demand. In particular, rather substantive reviews are cited in publications [1,9-11].

Two-component water quality models, where the processes of formation of water quality are estimated by oxygen demand (processes of biochemical oxidation of organic compounds) and its supply (process of atmospheric aeration).

New tendencies are observed in modeling of water quality [12]: returning to the classic models, in which DO concentration is function of disintegration of dissolved organics and natural processes (atmospheric aeration). Ratio "DO-BOD” is described by the classical model of Streeter-Phelps, in which equations of processes, based on assumptions of first-order kinetics [1, 3, 14] were analytically solved by Phelps and Streeter for a river section, and today are widely used in calculations [1, 15-19].

Prediction of the oxygen regime of the river Seversky Donets on a separate section with the help of the methods of mathematical modeling is considered in paper [7].

It is proposed to determine coefficient of biochemical oxidation rate and biochemical oxygen demand with the use of tables, specially calculated by the author [15]. To determine the specified theoretical substances, we need a pair of experimentally obtained values of $\mathrm{BOD}_{\mathrm{T}}$ and $\mathrm{BOD}_{2 \mathrm{~T}}$ (biochemical oxygen demand within the period of time $\mathrm{T}$ and $2 \mathrm{~T}$ days respectively). In this case, to calculate the aforesaid theoretical magnitudes, in addition to the measured values of $\mathrm{BOD}_{5}$, it is necessary to measure the value (for the same water sample) of $\mathrm{BOD}_{10}$. For calculation of these magnitudes, the author supplemented the classic Streeter-Phelps equations with one more equation. This made it possible to calculate the indicators more accurately. But the advantage of this method it at the same time its disadvantage. In practice of water sites monitoring, measuring $\mathrm{BOD}_{5}$, which corresponds to value of $\mathrm{T}=5$ days, is commonly accepted, while measuring $\mathrm{BOD}_{10}$ was not and is not carried out.

Modifications of the classic model of Streeter-Phelps are applied in papers [16-18]. The biofilter and convective and diffuse terms are introduced to the model.

The task of determining coefficients of Streeter-Phelps equations for sea water is considered in article [19]. Coefficient of biochemical oxidation is determined experimentally. To determine reaeration coefficient, it is proposed to use the search technique that eliminates uncertainty when solving a system of equations.

The issue of modeling and planning of systems of water resources management under conditions of uncertainty is considered in paper [20]. Work [21] is dedicated to application of the theory of games for determining and interpretation of behavior of parties of water use. Article [22] considered the use of multicriterial analysis in problems of water resources management.

Authors of [23] propose a decision support model for state water agencies. It is the method of stochastic objective programming with two goals, one of which relates to the farm management, the other - to impact on the environment.

Authors of paper [24] developed the overall integrated model of optimization of water industry management for effective representation of a wide range of management options.

The environmental condition of the basin of the Seversky Donets river on the whole and the impact of waste water on it, as well as oxygen regime, are analyzed in papers $[8,25,26]$.

The considered papers give examples of modeling of indicators of biochemical oxygen demand and of dissolved oxygen with the use of the Streeter-Phelps equations. Au- 
thors of [7-14] proposed to determine the model parameters for a particular water site through solving classical equations. To enhance the accuracy of the model, other authors [16-18] propose to introduce additional parameters to it or to analyze BOD of one and the same water sample in the double intervals of time [15]. A number of papers highlight the problems of modeling directly in management of water resources [20-24].

But the available sources on this issue did not consider the problem of determining of parameters for models of biochemical oxygen of demand and dissolved oxygen based of system long-term observations. It is important that such observations should be conducted through a network of control sites (e. g., basin of the Seversky Donets river). This enables us to determine the rate of processes of cleaning (pollution) of a reservoir, to construct an appropriate model and to verify its adequacy. The resulting model can be applied to similar sections of both rivers and reservoirs.

Under today's conditions of transition of Ukraine to the basin principle of water resources management, the problem of the most optimal use of the existing network of observations is relevant. Ecological information, collected through long-term observations can serve as the basis for verification of the models of hydro-environmental processes.

By the project purpose, the reservoir is the main source of the centralized economic water supply of Donbas, apart from this, it is supposed to be used for irrigation, needs of fishing industry and rest of the population [2].

Research in dynamics of oxygen indicators is relevant, given the great importance of the reservoir for providing of low-water regions of Ukraine with drinking water. Indicators of oxygen are integral magnitudes that characterize water quality as a whole. That is why under conditions when is not possible to conduct a fully-fledged chemical analysis of water, and a management decision on the environmental situation in the reservoir is required, analysis of oxygen indicators and modeling of their dynamics will offer primary information for making managerial decision.

It is proposed to determine parameters of the classical model of the Streeter-Phelps oxygen indicators, based on retrospective data, taken at successive points of observations directly in the reservoir and in the low water of the Oskil river. Using retrospective data will also allow taking into account seasonal impact on fluctuation of oxygen indicators.

\section{The aim and objectives of the study}

The aim of present research is to study dynamics and to construct a mathematical model for prediction of oxygen regime indicators (BOD and DO) of the Chervonooskil reservoir based on the classical Streeter-Phelps model.

To accomplish the set goal, the following tasks had to be solved:

- to conduct retrospective analysis of the data of oxygen indicators of the reservoir;

- to identify parameters of the Streeter-Phelps model for the reservoir.

\section{Materials and methods for studying the oxygen regime of Chervonooskil reservoir}

The Chervonooskil reservoir refers to the type of plain water-bed rivers. The length of the reservoir is $85.0 \mathrm{~km}$, its average width is $1.44 \mathrm{~km}$, its average depth is $3.86 \mathrm{~m}$, the area of the water mirror at the normal supporting level is 12270 ha. The reservoir is one of the key sources of the drinking water supply system for cities of Donbas. This system consists of the main Seversky Donets-Donbas canal, which is $132 \mathrm{~km}$ long, a number of waterworks, 5 backup reservoirs and the main regulating Chervonooskil reservoir.

The ecological state of the Seversky Donets river cannot always provide uninterrupted supply of water, especially in the dry period. Then the canal is supplied at the expense of the Chervonooskil reservoir. The specialists call it "the regulating reservoir".

The reservoir has no clearly determined bed of the river Oskil, it is silted with sediments, brought from the water collecting area in the period of spring floods. The average amount of sediment material is in the range from half a meter at the lower parts of the reservoir to one meter in its upper parts.

The reservoir is eutrophic - with high content of nutrients, a huge layer of silt deposits with a high content of organic matter. Water transparency is low. Water vegetation and plankton are common.

The research in oxygen regime of the Chervonooskil reservoir was carried out based of materials of water quality of the control laboratory of Sloviansk regional production management of CE "Company "Water of Donbas" (Ukraine). The source data for the study are given in Table 1-4.

Table 1

Monthly average values of $\mathrm{BOD}_{5}\left(\mathrm{mg} / \mathrm{dm}^{3}\right)$ for Chervonooskil reservoir

\begin{tabular}{|c|c|c|c|c|c|c|c|c|c|c|c|c|}
\hline \multirow{2}{*}{ Year } & \multicolumn{10}{|c|}{ Month } \\
\cline { 2 - 14 } & I & II & III & IV & V & VI & VII & VIII & IX & X & XI & XII \\
\hline 2010 & 1.5 & 1.5 & 1.9 & 1.4 & 1.9 & 1.7 & 1.4 & 1.5 & 2.2 & 2.3 & 2.2 & 1.8 \\
\hline 2011 & 1.9 & 1.8 & 1.9 & 2.2 & 2.1 & 1.4 & 1.6 & 2.2 & 1.6 & 1.7 & 1.8 & 1.6 \\
\hline 2012 & 1.5 & 1.6 & 1.9 & 2.3 & 1.7 & 1.8 & 2.4 & 2.6 & 2.7 & 2 & 1.8 & 1.6 \\
\hline 2013 & 1.5 & 1.6 & 2.0 & 2.3 & 1.3 & 1.1 & 1.4 & 1.1 & 1.0 & 1.1 & 1.5 & 1.1 \\
\hline 2014 & 1.7 & 1.5 & 1.5 & 1.6 & 1.5 & 1.6 & 1.4 & 2.8 & 2.5 & 2.2 & 1.4 & 1.4 \\
\hline
\end{tabular}

Table 2

Monthly average values of $\mathrm{BOD}_{5}\left(\mathrm{mg} / \mathrm{dm}^{3}\right)$ for Oskil river (downstream water)

\begin{tabular}{|c|c|c|c|c|c|c|c|c|c|c|c|c|}
\hline \multirow{2}{*}{ Year } & \multicolumn{10}{|c|}{ Month } \\
\cline { 2 - 5 } & I & II & III & IV & V & VI & VII & VIII & IX & X & XI & XII \\
\hline 2010 & 1.4 & 1.8 & 2.0 & 1.5 & 2.0 & 2.1 & 1.9 & 1.9 & 2.4 & 2.2 & 1.9 & 1.7 \\
\hline 2011 & 1.8 & 2.0 & 1.8 & 2.3 & 2.0 & 1.7 & 1.8 & 2.0 & 1.2 & 2.0 & 1.9 & 1.6 \\
\hline 2012 & 1.1 & 1.8 & 2.1 & 2.1 & 2.0 & 1.7 & 2.5 & 2.4 & 2.6 & 1.9 & 1.8 & 1.7 \\
\hline 2013 & 1.5 & 1.7 & 1.8 & 2.0 & 1.2 & 1.1 & 1.3 & 1.2 & 1.0 & 1.1 & 1.6 & 1.2 \\
\hline 2014 & 1.6 & 1.6 & 1.6 & 1.4 & 1.6 & 1.5 & 1.4 & 2.1 & 1.8 & 2.0 & 1.6 & 1.4 \\
\hline
\end{tabular}

Table 3

Monthly average values of dissolved oxygen $\left(\mathrm{mg} / \mathrm{dm}^{3}\right)$ for Chervonooskil reservoir

\begin{tabular}{|c|c|c|c|c|c|c|c|c|c|c|c|c|}
\hline \multirow{2}{*}{ Year } & \multicolumn{10}{|c|}{ Month } \\
\cline { 2 - 12 } & I & II & III & IV & V & VI & VII & VIII & IX & X & XI & XII \\
\hline 2010 & 13.9 & 13.9 & 15.1 & 16.9 & 18.6 & 12.7 & 12.2 & 16.2 & 14.4 & 12.2 & 12.0 & 12.8 \\
\hline 2011 & 13.3 & 14.8 & 14.1 & 19.6 & 14.4 & 12.5 & 12.4 & 14.6 & 10.4 & 10.5 & 10.6 & 10.6 \\
\hline 2012 & 12.0 & 12.3 & 15.1 & 17.2 & 14.1 & 12.0 & 16.6 & 18.3 & 12.1 & 11.5 & 12.1 & 8.9 \\
\hline 2013 & 15.7 & 14.9 & 15.8 & 16.1 & 11.4 & 8.8 & 10.0 & 10.0 & 8.9 & 10.8 & 12.1 & 10.0 \\
\hline 2014 & 15.7 & 13.5 & 17.6 & 17.8 & 12.2 & 10.1 & 10.8 & 17.4 & 16.7 & 13.2 & 13.2 & 13.3 \\
\hline
\end{tabular}


Table 4

Average monthly values of dissolved oxygen $\left(\mathrm{mg} / \mathrm{dm}^{3}\right)$ for Oskil river (downstream water)

\begin{tabular}{|c|c|c|c|c|c|c|c|c|c|c|c|c|}
\hline \multirow{2}{*}{ Year } & \multicolumn{10}{|c|}{ Month } \\
\cline { 2 - 13 } & I & II & III & IV & V & VI & VII & VIII & IX & X & XI & XII \\
\hline 2010 & 12.7 & 13.2 & 14.1 & 14.7 & 12.9 & 9.9 & 6.2 & 6.3 & 12.6 & 9.6 & 11.3 & 11.5 \\
\hline 2011 & 12.1 & 12.7 & 12.8 & 16.5 & 13.7 & 8.9 & 9.3 & 8.6 & 10.1 & 9.4 & 9.5 & 9.6 \\
\hline 2012 & 12.2 & 10.2 & 12.9 & 15.7 & 9.3 & 9.9 & 8.2 & 6.1 & 9.2 & 10.3 & 11.5 & 8.4 \\
\hline 2013 & 14.8 & 14.4 & 17.1 & 15.6 & 9.7 & 8.6 & 9.9 & 9.3 & 9.1 & 10.6 & 11.4 & 9.3 \\
\hline 2014 & 14.8 & 11.9 & 15.3 & 14.7 & 9.7 & 10.0 & 10.0 & 9.6 & 13.4 & 11.6 & 12.2 & 12.8 \\
\hline
\end{tabular}

For calculation of parameters of the model, we used equations of processes by Streeter-Phelps scheme. They determine the ratio between concentration of dissolved oxygen and biochemical oxygen demand within a certain time interval and are described by the system of equations

$$
\begin{aligned}
& \frac{\mathrm{d} C_{1}}{\mathrm{~d} t}=-k_{1} \cdot C_{1}, \\
& \frac{\mathrm{d} C_{2}}{\mathrm{~d} t}=k_{1} \cdot C_{1}-k_{2} \cdot C_{2},
\end{aligned}
$$

where $k_{1}$ is the mineralization coefficient (coefficient of biochemical oxidation of organic substances, $1 /$ day); $k_{2}$ is the reaeration coefficient, $1 /$ day), $C_{1}=\mathrm{BOD}, \mathrm{mg} / \mathrm{l}$; and $C_{2}=$ $=D O_{S}-D O$. Here, $C_{2}$ is the oxygen deficiency, $D O_{S}$ is the limit DO concentration in water (no wastes), $\mathrm{mg} / \mathrm{l}, D O$ is the DO concentration in water at an arbitrary moment of time, mg/l.

For the reservoir, which has a constant flow velocity $U$, magnitude $t$ can be interpreted as duration $(t=x / U)$ of the process flow on the section with the length of $x$ at flow velocity $U$, and then the system of equations (1) and (2) takes an analytical form of solution:

$$
\begin{aligned}
& C_{1}=C_{1,0} \cdot e^{-k_{1} t}, \\
& C_{2}=\frac{k_{1} \cdot C_{1,0}}{k_{2}-k_{1}} \cdot\left(e^{-k_{1} t}-e^{-k_{2} t}\right)+C_{2,0} \cdot e^{-k_{2} t},
\end{aligned}
$$

where $C_{1,0}$ is the BOD at the initial moment of time, $C_{2,0}$ is the oxygen deficiency at the initial moment of time, caused by the source of pollution.

In this case equation (1) describes the process of decomposition of organic substance and equation (2) characterizes the curve of a decrease in dissolved oxygen. The curve of a decrease shows that oxygen deficiency reaches its maximum at a certain critical distance from wastewater discharge [3].

Multipliers $C_{1,0}$ and $C_{2,0}$ in equations (3) and (4) are determined experimentally, coefficients $k_{1}$ and $k_{2}$ are unknown.

From equation (3), mineralization coefficient $k_{1}$ can be represented in the form

$$
k_{1}=t^{-1} \cdot \ln \frac{C_{1,0}}{C_{1}} .
$$

Reaeration coefficient $k_{2}$ is found from equation (4)

$$
k_{2}=\frac{C_{1,0} \cdot k_{1} \cdot e^{-k_{1} t}}{C_{2}} .
$$

\section{Results of research into oxygen regime in Chervonooskil reservoir}

Dynamics of seasonal fluctuations of dissolved oxygen on the surface of the Chervonooskil reservoir and in downstream water of the river Oskil over 2010-2014 is shown in Fig. $1-3$.

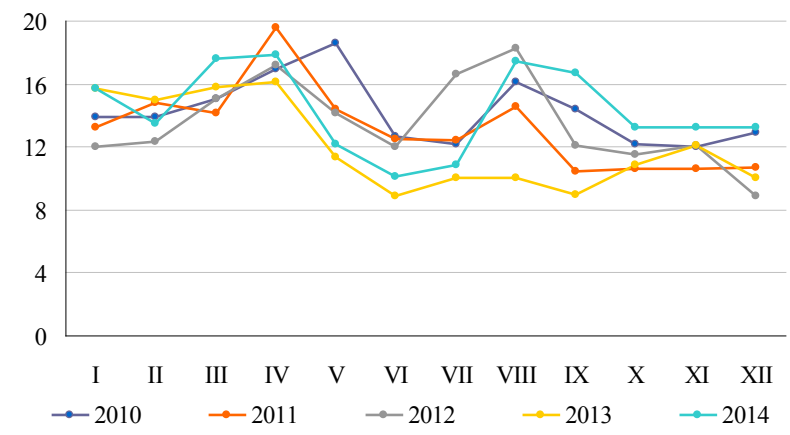

Fig. 1. Seasonal changes in the content of dissolved oxygen $\left(\mathrm{mg} / \mathrm{dm}^{3}\right.$ ) of Chervonooskil reservoir over 2010-2014

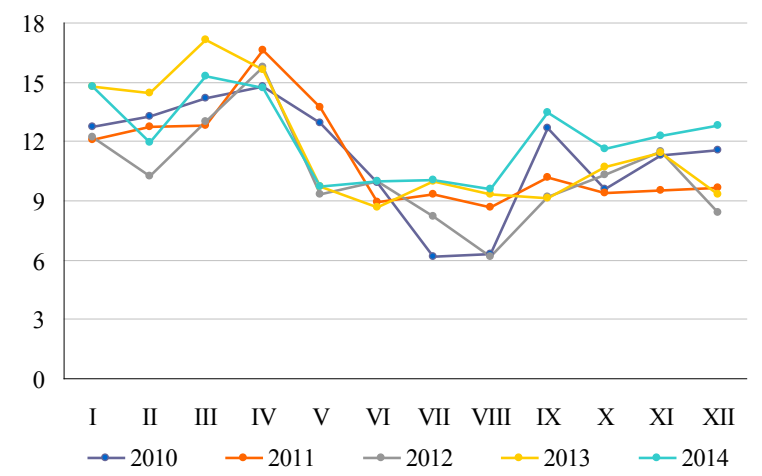

Fig. 2. Seasonal changes in the content of dissolved oxygen $\left(\mathrm{mg} / \mathrm{dm}^{3}\right)$ in water of river Oskil (downstream water) over 2010-2014

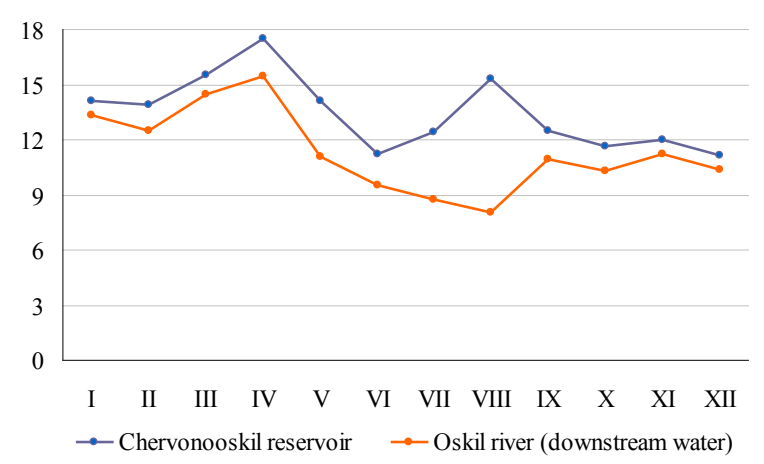

Fig. 3. Seasonal average annual changes in content of dissolved oxygen $\left(\mathrm{mg} / \mathrm{dm}^{3}\right)$ in water of Chervonooskil reservoir and Oskil river (downstream water)

The presented diagrams show only seasonal fluctuations in content of dissolved oxygen - an increase in its content in the cold season and a decrease in the warm season.

The diagram (Fig. 3) shows that the content of dissolved oxygen in the reservoir in the warm season considerably exceeds the content of oxygen in the river, which is explained by significantly larger area of the water mirror and, accordingly, greater capacity of the reservoir to photosynthesis of aquatic vegetation. 
For subsequent identification of retrospective tendencies of changes in the content of dissolved oxygen in the Chervonooskil reservoir and the river Oskil (downstream water), we analyzed the changes by average annual indicators (Fig. 4).

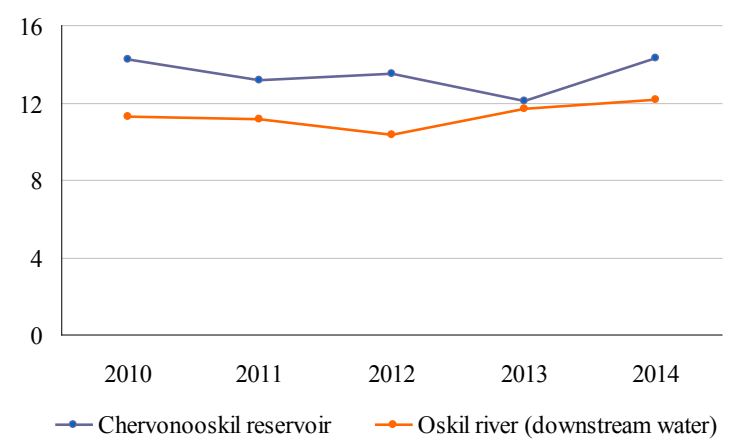

Fig. 4. Changes in the content of dissolved oxygen $\left(\mathrm{mg} / \mathrm{dm}^{3}\right)$ in water of Chervonooskil water reservoir and the river Oskil (downstream water) by average annual indicators for 2010-2014

Both diagrams (Fig. 4) show indistinct tendency towards increasing of dissolved oxygen both in the water reservoir and in the river Oskil, which may be explained by a decrease in anthropogenic load on the water body basin through economic decline, caused by the adverse political situation in the country.

Dynamics of seasonal fluctuations of BOD on the surface of the Chervonooskil reservoir and in downstream water of Oskil town within 2010-2014 is shown in Fig. 5-7.

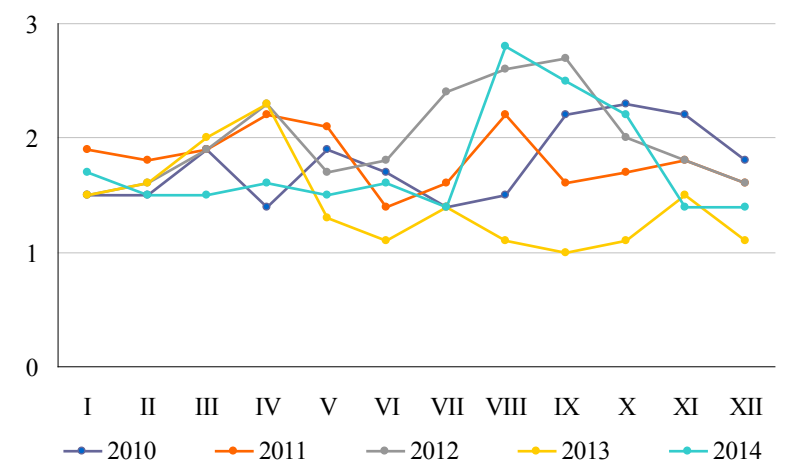

Fig. 5. Seasonal changes in the content of BOD $\left(\mathrm{mg} / \mathrm{dm}^{3}\right)$ in water of the Chervonooskil reservoir over 2010-2014

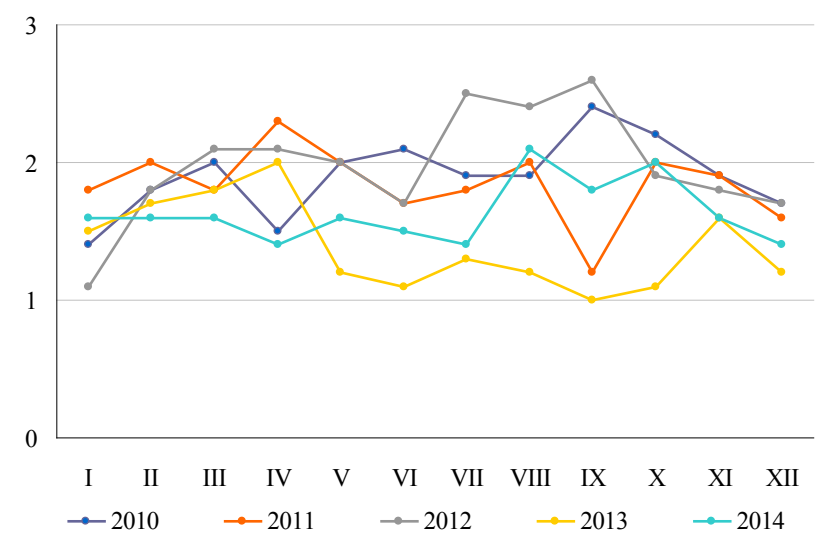

Fig. 6. Seasonal changes in content of BOD $\left(\mathrm{mg} / \mathrm{dm}^{3}\right)$ in water of the Oskil river (downstream water) over 2010-2014

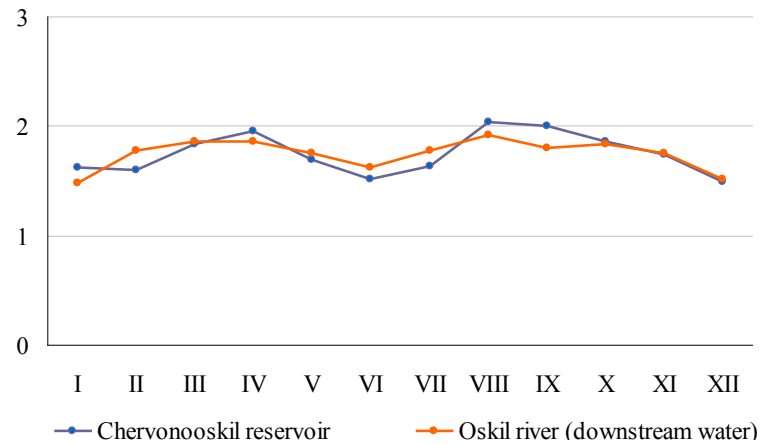

Fig. 7. Seasonal average annual changes in the content of BOD $\left(\mathrm{mg} / \mathrm{dm}^{3}\right)$ in water of Chervonooskil reservoir and the Oskil river (downstream water)

Presented diagrams (Fig. 7) demonstrate virtually synchronous fluctuations in BOD indicator in the Chervonooskil reservoir and in the Oskil river (downstream water) within a year. A decrease in BOD in summer can be explained by an increase in oxygen supply to the reservoir due to photosynthesis of aquatic vegetation.

Let us examine the tendencies of changes in BOD content in water of the Chervonooskil reservoir and the Oskil river (downstream water); for this, we will carry out analysis of changes by average annual indicators (Fig. 8).

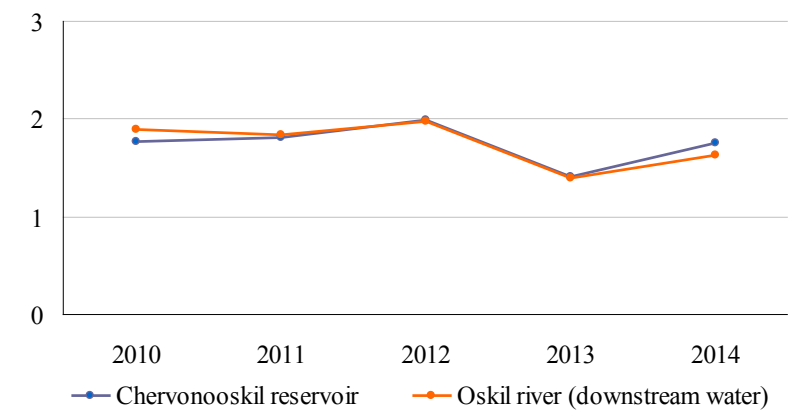

Fig. 8. Changes in BOD content $\left(\mathrm{mg} / \mathrm{dm}^{3}\right)$ in water of Chervonooskil reservoir and river Oskil (downstream water) by average annual indicators over 2010-2014

Similar to the case of dissolved oxygen, presented diagrams show an indistinct tendency towards a decrease in BOD indicator both in water of the reservoir, and in the Oskil river. This is explained by a decrease in anthropogenic load on the basin of the water body due to the economic decline, which is a consequence of unfavorable political situation in the country.

To determine parameters of the model of dynamics of oxygen regime in the Chervonooskil reservoir, i. e. value of coefficients $k_{1}$ (coefficient of biochemical oxidation of organic substances) and $k_{2}$ (reaeration coefficient), we will use empirical data of Table 1-4 and calculate from formulas (5) and (6). For calculations, it is possible to use both special software and usual office data processing programs.

Temperature of environment is one of the most important factors that affect oxygen solubility in water and the rate of biochemical processes. That is why it is appropriate to calculate parameters $k_{1}$ and $k_{2}$ for each month.

Table 5 gives values of coefficients $k_{1}$ and $k_{2}$. 
Table 5

Calculated values of coefficients $k_{1}$ and $k_{2}$

\begin{tabular}{|c|c|c|}
\hline Month & $k_{1}$ & $k_{2}$ \\
\hline January & -0.00049 & -0.00092 \\
\hline February & 0.00058 & 0.00079 \\
\hline March & 0.000000 & 0.00000 \\
\hline April & -0.00019 & -0.00021 \\
\hline May & 0.00014 & 0.00008 \\
\hline June & 0.00048 & 0.00036 \\
\hline July & 0.00049 & 0.00021 \\
\hline August & 0.00007 & 0.00002 \\
\hline September & -0.00020 & -0.00031 \\
\hline October & 0.00007 & 0.00010 \\
\hline November & -0.00007 & -0.00016 \\
\hline December & 0.00008 & 0.00014 \\
\hline
\end{tabular}

Thus, the original data for calculation of coefficients $k_{1}$ and $k_{2}$ are averaged monthly values of correspondent indicators of oxygen regime of many years over the period of 2010-2014.

\section{Discussion of results of research into oxygen regime in Chervonooskil water reservoir}

Based on calculated coefficients $k_{1}$ and $k_{2}$, we calculated mathematical models of values of BOD and oxygen deficiency. Adequacy verification of the calculated model is demonstrated in the appropriate diagrams (Fig. 9, 10), which show the curves of average annual values of indicators, model values for 2014, and actually received values of indicators of BOD and of deficiency of dissolved oxygen.

Correlation coefficient between modeled and empirical BOD value is 0.86 , which can be considered acceptable in view of the results of other researchers [17], who indicate that all models, proposed for description of interaction between DO and BOD, are influenced by the fact of inaccuracy of assigning parameters for this model, derived from the experiment (magnitude of error can be up to $40 \%$ ).

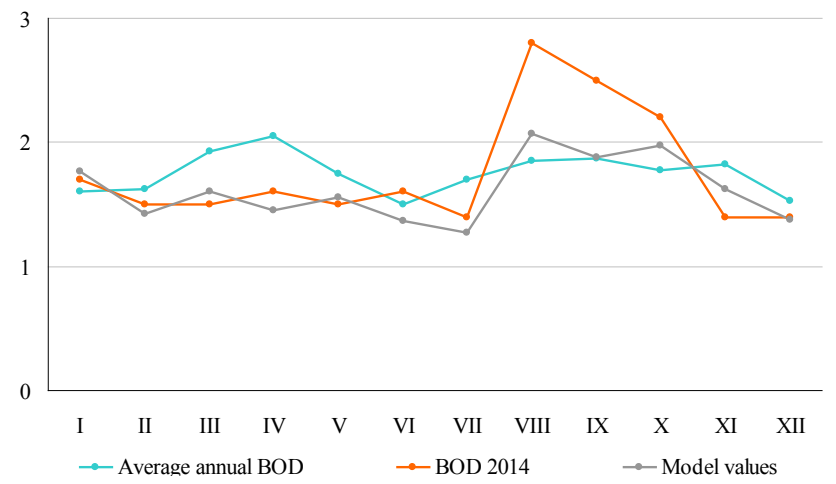

Fig. 9. Empirical and model values of BOD indicators $\left(\mathrm{mg} / \mathrm{dm}^{3}\right)$

Correlation coefficient between results of modeling of values of dissolved oxygen deficiency and empirical values for 2014 (Fig. 10) is 0.7.
The merits of the conducted study include the possibility of operative processing of data of monitoring the surface water sources. The used model enables us to perform calculations without using special mathematical programs. This reduces requirements both to hardware and the personnel that performs the water body control.

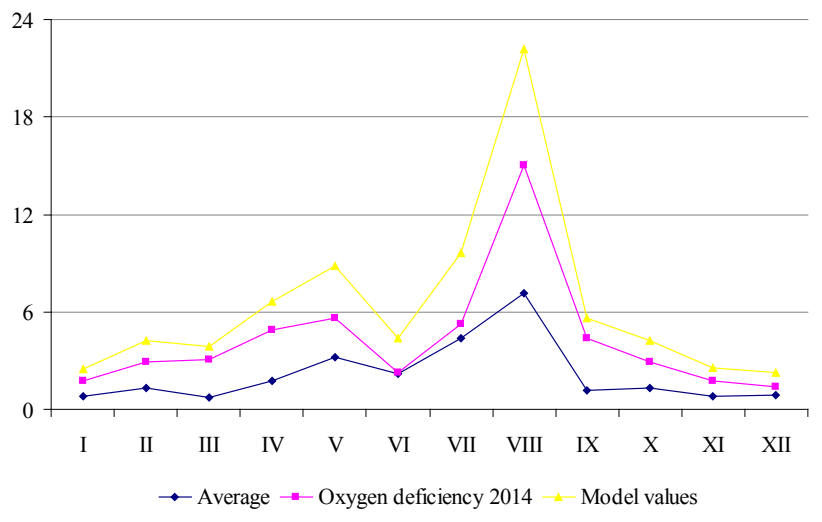

Fig. 10. Empirical and predictive values of indicators of dissolved oxygen deficiency $\left(\mathrm{mg} / \mathrm{dm}^{3}\right)$

The shortcomings include a limited set of components of the model, used in this study, but in this case, it is justified by the goal of the study.

The main purpose of the received model is to predict indicators of BOD and of dissolved oxygen deficiency by the results of operative monitoring. The model can be considered adequate for prediction under conditions of water reservoir and used during current observations of relevant indicators (during operative monitoring).

This study is a continuation of the study of ecological state of the basin of the Seversky Donets river. It seems promising to include in the equations the model variables that characterize hydrological and temperature indicators of a studied site in order to determine the parameters more accurately.

\section{Conclusions}

1. Based on retrospective observational data for 2010-2014, we carried out an analysis of dynamics of indicators of BOD and of dissolved oxygen of the Chervonooskil water reservoir and the Oskil river (downstream water). The tendencies towards improving oxygen regime of the reservoir were detected: an increase in concentration of dissolved oxygen and a decrease in BOD by average annual indicators. This is explained by a decrease in anthropogenic load on the basin of the water body due to the economic decline, which is a consequence of unfavorable political situation in the country.

2. Parameters $k_{1}$ (coefficient of biochemical oxidation of organic substances) and $k_{2}$ (reaeration coefficient) of the Streeter-Phelps model for a water reservoir were calculated. Given the influence of temperature on oxygen solubility and on the rate of biochemical processes, calculation of parameters $k_{1}$ and $k_{2}$ was performed for each month of the year. Correlation coefficient between the modeled and empirical values of biochemical demand of oxygen is 0.86 , which can be considered acceptable for such research. 


\section{References}

1. Pryazhinskaya, V. G. Komp’yuternoe modelirovanie v upravlenii vodnymi resursami [Text]: monografiya / V. G. Pryazhinskaya, D. M. Yaroshevskiy, L. K. Levit-Gurevich. - Moscow: FIZMATLIT, 2002. - 496 p.

2. Vyshnevskyi, V. I. Richky i vodoimy Ukrainy. Stan i vykorystannia [Text] / V. I. Vyshnevskyi. - Kyiv: Vipol, 2000. - 376 p.

3. Osadchyi, V. I. Kysnevyi rezhym poverkhnevykh vod Ukrainy [Text] / V. I. Osadchyi, N. M. Osadcha // Nauk. pr. UkrNDHMI. 2006. - Issue 256. - P. 265-285.

4. Osadchiy, V. I. Mnogoletnyaya dinamika i vnutrigodovoe raspredelenie rastvorennogo kisloroda v poverhnostnyh vodah Ukrainy [Text]: 3 vseukr. nauk. konf. / V. I. Osadchiy // Hidrolohiya, hidrokhimiya, hidroekolohiya. - 2006. - P. 122-123.

5. Romanenko, V. D. Metodyka ekolohichnoi otsinky yakosti poverkhnevykh vod za vidpovidnymy katehoriyamy [Text] / V. D. Romanenko, V. M. Zhukynskyi, O. P. Oksiyuk. - Kyiv: Symvol-T, 1998. - 28 p.

6. Hrytsenko, A. V. Suchasnyi ekolohichnyi stan ukrainskoi chastyny richky Siverskyi Donets (ekspedytsiyni doslidzhennia) [Text] / A. V. Hrytsenko, O. H. Vasenko, A. V. Kolisnyk et. al.; A. V. Hrytsenko, O. H. Vasenko (Eds.). - Kharkiv: VPP «Kontrast», 2011. $-340 \mathrm{p}$.

7. Bezsonnyi, V. L. Prohnozuvannia kysnevoho rezhymu richky Siverskyi Donets metodamy matematychnoho modeliuvannia [Text] / V. L. Bezsonnyi, O. V. Tretiakov, A. M. Kravchuk, Yu. F. Statsenko // Budivnytstvo, materialoznavstvo, mashynobuduvannia. 2016. - Issue 93. - P. 113-119.

8. Ukhan, O. O. Kharakterystyka kysnevoho rezhymu poverkhnevykh vod baseinu r. Siverskyi Donets [Text] / O. O. Ukhan, N. M. Osadcha // Naukovi pratsi UkrNDHMI. - 2010. - Issue 259. - P. 199-216.

9. Mokin, V. B. Matematychni modeli ta prohramy dlia otsiniuvannia yakosti richkovykh vod [Text] / V. B. Mokin, B. I. Mokin. Vinnytsia: Universum-Vinnytsia, 2000. - 152 p.

10. Tretiakov, O. V. Osnovni metody matematychnoho modeliuvannia dlia metodychnoho zabezpechennia baseinovoho pidkhodu v upravlinni yakistiu vodnykh resursiv [Text] / O. V. Tretiakov, V. L. Bezsonnyi // Systemy obrobky informatsii. - 2016. Issue 8 (145). - P. 194-199.

11. Rogalev, A. N. Determinirovannye i stohasticheskie metody ocenki kachestva vody v usloviyah neopredelennosti [Text]: XIV Ross. konf. / A. N. Rogalev // Raspredelennye informacionnye i vychislitel'nye resursy (DICR-2012). - 2012. - P. 101-112.

12. Danilov-Danil'yan, V. I. Upravlenie vodnymi resursami v usloviyah klimaticheskih izmeneniy [Text] / V. I. Danilov-Danil'yan, V. G. Pryazhinskaya // Obosnovanie strategiy upravleniya vodnymi resursami. - Moscow: Nauchniy mir, 2006. - P. 62-76.

13. Druzhinin, N. I. Matematicheskoe modelirovanie i prognozirovanie zagryazneniya poverhnostnyh vod sushi [Text]: monografiya / N. I. Druzhinin, A. I. Shishkin. - Leningrad: Gidrometeoizdat, 1989. - 390 p.

14. Bek, M. B. Modelirovanie soderzhaniya rastvorennogo kisloroda na uchastke reki, dalekom ot estuariya [Text] / M. B. Bek; Yu. M. Svirezheva (Ed.) // Matematicheskie modeli kontrolya zagryazneniya vody. - Moscow: Mir, 1981. - P. 165-199.

15. Gotovcev, A. V. Opredelenie skorosti biohimicheskogo okisleniya i biohimicheskoy potrebnosti v kislorode tablichnym metodom [Text]: Vseross. nauch. konf. / A. V. Gotovcev // Nauchnoe obespechenie realizacii «Vodnoy strategii Rossiyskoy Federacii na period do 2020 g.». - Petrozavodsk, 2015. - P. 263-272.

16. Mihaylov, M. D. Ob odnoy modifikacii modeli Stritera-Felpsa i ee chislennoy realizacii s pomoshch'yu mnogoprocessornyh vychislitel'nyh sistem [Text] / M. D. Mihaylov // Vestnik tomskogo gosudarstvennogo universiteta. Seriya: Matematika i mekhanika. - 2010. - Issue 1 (9). - P. 39-46.

17. Rogalev, A. N. Chislennaya realizaciya modeli Stritera-Felpsa i ee modifikaciy s uchetom neopredelennosti dannyh [Text]: mater. mezhdunar. konf. / A. N. Rogalev, A. A. Rogalev // Kubaturnye formuly, metody Monte-Karlo i ih prilozheniyaposvyashchennoy 90-letiyu so dnya rozhdeniya I. P. Mysovskih. - Krasnoyarsk, 2011. - P. 100-104.

18. Ckhay, A. A. Matematicheskoe modelirovanie kachestva vody v proektiruemom vodohranilishche na osnove RK-BPK [Text] / A. A. Ckhay // Izvestiya Altayskogo gosudarstvennogo universiteta. - 2012. - Vol. 2, Issue 1 (73). - P. 123-126.

19. Volkova, T. A. Osobennosti resheniya uravneniy Stritera-Felpsa dlya ocenki ekologicheskoy bezopasnosti morskoy akvatorii [Text] / T. A. Volkova, A. I. Kondrat'ev // Transportnoe delo Rossii. - 2011. - Issue 7 (92). - P. 120-122.

20. Miao, D. Y. Optimization Model for Planning Regional Water Resource Systems under Uncertainty [Text] / D. Y. Miao, Y. P. Li, G. H. Huang, Z. F. Yang, C. H. Li // Journal of Water Resources Planning and Management. - 2014. - Vol. 140, Issue 2. P. 238-249. doi: 10.1061/(asce)wr.1943-5452.0000303

21. Madani, K. Game theory and water resources [Text] / K. Madani // Journal of Hydrology. - 2010. - Vol. 381, Issue 3-4. P. 225-238. doi: 10.1016/j.jhydrol.2009.11.045

22. Hajkowicz, S. A Review of Multiple Criteria Analysis for Water Resource Planning and Management [Text] / S. Hajkowicz, K. Collins // Water Resources Management. - 2006. - Vol. 21, Issue 9. - P. 1553-1566. doi: 10.1007/s11269-006-9112-5

23. Bravo, M. Applying stochastic goal programming: A case study on water use planning [Text] / M. Bravo, I. Gonzalez // European Journal of Operational Research. - 2009. - Vol. 196, Issue 3. - P. 1123-1129. doi: 10.1016/j.ejor.2008.04.034

24. Zoltay, V. I. Integrated Watershed Management Modeling: Generic Optimization Model Applied to the Ipswich River Basin [Text] / V. I. Zoltay, R. M. Vogel, P. H. Kirshen, K. S. Westphal // Journal of Water Resources Planning and Management. - 2010. - Vol. 136, Issue 5. - P. 566-575. doi: 10.1061/(asce)wr.1943-5452.0000083

25. Tretiakov, O. V. Improving the environmental safety of drinking water supply in Kharkiv region (Ukraine) [Text] / O. V. Tretiakov, T. O. Shevchenko, V. L. Bezsonnyi // Eastern-European Journal of Enterprise Technologies. - 2015. - Vol. 5, Issue 10 (77). P. 40-49. doi: 10.15587/1729-4061.2015.51398

26. Tretiakov, O. V. Otsinka vplyvu stichnykh vod na ekolohichnyi stan richky Siverskyi Donets [Text] / O. V. Tretiakov, V. L. Bezsonnyi // Vestnik HNADU. - 2015. - Issue 71. - P. 103108. 